\title{
Faktor-Faktor yang Mempengaruhi Kepuasan Pengguna Jembatan Penyeberangan Orang (JPO) pada Pelayanan Strategis Berskala Nasional di Kota Surabaya
}

\author{
Factors Affecting Users Satisfaction for Pedestrian Bridge in Strategic \\ National Service in Surabaya City
}

\author{
Amanda Ristriana Pattisinai ${ }^{1 a)}$ \& Fitri Rohmah Widayanti ${ }^{1 b)}$ \\ ${ }^{1)}$ Program Studi Transportasi, Teknik Sipil, Universitas Negeri Surabaya (Unesa), Surabaya.
}

Koresponden : ${ }^{\text {a) }}$ amandaristriana@unesa.ac.id \& ${ }^{\text {b) }}$ fitrirohmah@unesa.ac.id

\begin{abstract}
ABSTRAK
Tujuan dari penelitian ini adalah untuk mengetahui penilaian fasilitas dari Jembatan Penyeberangan Orang (JPO) di kota Surabaya berdasarkan penilaian dari pengguna. Untuk mengeksplorasi ini, kami mensurvei Jalan Gubernur Suryo - SMA Negeri 6 Surabaya (pusat kawasan pemerintahan skala regional dan kawasan pendidikan), Jalan Profesor Dr. Mustopo (kawasan penyedia sarana kesehatan dengan skala pelayanan regional dan kawasan pendidikan tinggi), dan Jalan Pemuda - Plaza Surabaya (kawasan bisnis, perkantoran dan perdagangan), Indonesia sebagai kawasan pelayanan strategis skala regional di Kota Surabaya $(\mathrm{N}=120)$. Metode yang digunakan adalah Importance Performance Analysis (IPA) yang merupakan ukuran tingkat kepuasan layanan yang masuk kuadran pada peta Importance Performance Matrix. Dalam metode ini, perlu untuk mengukur tingkat kesesuaian untuk mengetahui seberapa besar pengguna merasa puas dengan kinerja jembatan penyeberangan. Faktor yang paling membuat pengguna tidak puas adalah B2 yaitu lampu yang menyala di malam hari, diikuti oleh D1 (pegangan tangan di Jembatan Pedestrian yang mudah dijangkau dan tidak berkarat) dan D5 (bangunan yang dapat mengurangi getaran saat kendaraan melaju kencang) diatasnya.
\end{abstract}

Kata Kunci : manajemen fasilitas, JPO, pejalan kaki, kawasan pelayanan strategis.

\section{PENDAHULUAN}

Manajemen Aset adalah suatu tindakan pengelolaan aset, agar aset tersebut bisa memberikan manfaat yang sebesar-besarnya dengan biaya yang sekecil mungkin dan aset tersebut jangan sampai punah, kecuali memang sebaiknya harus dimusnahkan atau dihapuskan (Soemitro \& Suprayitno, 2018). Berbagai usaha dilakukan untuk mempertahankan aset milik pemerintah kota dewasa ini, namun demikian manajemen aset seringkali dianggap sebagai persoalan teknis sehingga dilakukan pemecahan masalah dengan pendekatan taktis saja (Giglio dkk, 2018). Padahal, berdasarkan riset yang dilakukan Shah dkk (2017), ditemukan fakta bahwa Asset Management Principles (AMP) sering kali tidak efektif dalam mengelola jalan raya beserta sarana prasarana pendukungnya, dan masih diperlukan komitmen yang kuat untuk meningkatkan kemampuan manajemen aset menuju manajemen yang efektif.

Ketidak efektifan pengelolaan aset jalan seperti Jalur Penyeberangan Orang (JPO) diindikasikan terjadi pada hampir keseluruhan JPO yang berada di Kota Surabaya. Di Surabaya, JPO telah lama hadir di tengah aktivitas warga, terutama di kawasan pusat 
kegiatan, yang telah diatur dalam Rencana Tata Ruang Wilayah Kota Surabaya Tahun 20142034, seperti Jalan Gubernur Suryo - SMA Negeri 6 Surabaya (pusat kawasan pemerintahan skala regional dan kawasan pendidikan), Jalan Profesor Dr. Mustopo (kawasan penyedia sarana kesehatan dengan skala pelayanan regional dan kawasan pendidikan tinggi), dan Jalan Pemuda - Plaza Surabaya (kawasan bisnis, perkantoran dan perdagangan) yang memiliki jembatan penyeberangan yang disiapkan pemerintah kota untuk memfasilitasi pejalan kaki untuk menyeberang, walaupun kegiatan ini tidak menjadi pilihan pengguna yang populer.

Pejalan kaki menjadi tidak tertarik menggunakan JPO bukan hanya karena tidak merasa aman, tetapi juga karena desain JPO yang tidak bersahabat. Hal ini menjadi alasan utama para pejalan kaki sering kali tidak menggunakan JPO dan malah menyeberang jalan di bawahnya. Pejalan kaki membuat keputusan berdasarkan lingkungan mereka: jika perilaku mereka berisiko, sering kali itu akibat infrastruktur yang tidak nyaman atau tidak memadai. Jarak tambahan yang harus dilalui pejalan kaki bila melalui JPO, tidak hanya menciptakan penghalang fisik bagi pejalan kaki yang tidak dapat menaiki tangga atau landai yang curam (disabel), tetapi juga menambah waktu dan upaya ekstra yang pasti akan dihindari oleh pejalan kaki dengan hanya menyeberang melalui lalu lintas dibawah JPO. Parahnya, lokasi halte angkutan umum selalu tidak jauh dari jembatan penyeberangan. Sehingga seringkali terjadi konflik antara lalu lintas kendaraan bermotor, angkutan umum yang berhenti, dan pejalan kaki (Anonymous, 2019).

Meskipun berjalan sangat penting untuk mengakses transportasi umum, lebih dari seperlima dari populasi pengguna jalan yang meninggal setiap tahun, bukannya pengendara mobil, motor atau bahkan sepeda, tetapi mereka adalah pejalan kaki. Hal ini menjadi ironi tersendiri bagi para pejalan kaki sehingga kegiatan ini menjadi tidak aman dan nyaman dilakukan. Meskipun kematian dan cedera pejalan kaki sering terjadi di banyak lokasi dan jumlahnya meningkat setiap tahun, keselamatan pejalan kaki masih belum mendapatkan perhatian yang tepat (Lakhotia dkk., 2019; Yannis \& Papadimitriou, 2007; Coppola \& Golombek, 2018). Usaha-usaha meningkatkan kualitas JPO diharapkan dapat memberi pemahaman bagi pejalan kaki bahwa mereka merupakan "warga kedua" dalam mengakses JPO dan menghindarkan JPO menjadi aset yang terbengkalai.

Keberhasilan berjalan kaki saat ini merupakan moda transportasi penting di negaranegara berkembang (Dong dkk, 2019). Namun demikian, infrastruktur pejalan kaki yang tidak memadai telah memaksa orang untuk beralih ke moda transportasi lain. Tidak hanya infrastruktur pejalan kaki yang terus diremehkan dalam perencanaan transportasi umum dan pengembangan kebijakan secara luar biasa di Asia Tenggara (Mateo-Babiano, 2016; MateoBabiano dkk, 2016), tetapi juga kebutuhan pejalan kaki tetap menjadi perhatian yang paling tidak diperhatikan oleh masyarakat.

Oleh karena itu pengetahuan tentang perilaku pengguna dapat membantu memahami kebutuhan pejalan kaki. Hal ini diharapkan bahwa menciptakan lingkungan jembatan pejalan kaki berdasarkan pada apa yang pengguna butuhkan adalah poin penting untuk keberhasilan kepuasan berjalan (Kim \& Seung, 2014; Golias dkk, 2004; Pešic \& Maslac, 2016). Kepuasan pengguna jembatan penyeberangan adalah penting karena lingkungan jalur pejalan kaki yang menyenangkan akan lebih mungkin untuk disukai lagi dan diteruskan sebagai perilaku yang berkelanjutan dilakukan (Iamtrakul \& Zhang, 2015). Berdasarkan hal tersebut, mengeksplorasi kepuasan berjalan melalui penilaian pengguna JPO adalah subjek yang sangat penting untuk diteliti. Penggunaan metode Importance - Performance Analysis (IPA) adalah untuk mengukur tingkat kepuasan layanan yang masuk kuadran pada peta Importance Performance Matrix. Metode ini dapat mengukur tingkat kesesuaian untuk mengetahui seberapa besar pelanggan merasa puas dengan kinerja jembatan penyeberangan, sehingga kemudian dapat dirumuskan strategi yang paling tepat untuk meningkatkan walkabilitas pada kawasan - kawasan pelayanan strategis di Surabaya. Oleh karena itu dilakukan penelusuran 
mengenai "Faktor-Faktor yang Mempengaruhi Kepuasan Pengguna Jalur Penyeberangan Orang (JPO) pada Kawasan Pelayanan Strategis Skala Regional di Kota Surabaya".

\section{STUDI PUSTAKA}

\section{Definisi Jembatan Penyeberangan Orang (JPO)}

Jembatan Penyeberangan Orang (JPO) merupakan media penyeberangan yang diperlukan manusia dalam melewati jalur lalu lintas. JPO sangat dibutuhkan, hal ini dipicu oleh kecelakaan yang menimpa para penyeberang. Walaupun sudah adanya fasilitas zebra cross namun dikarenakan alur penyeberangan tidak terpisah dengan alur pengendara kendaraan secara fisik sehingga ada kemungkinan terjadinya kecelakaan (Warpani, 1990).

JPO adalah jembatan penyeberangan yang bersilangan dengan jalan raya ataupun kereta api (Tamin, 2000), yang letaknya berapa diatas jalan tersebut yang diperuntukkan hanya untuk pejalan kaki yang menyeberang pada jalan raya atau jalur kereta tersebut.

JPO merupakan salah satu fasilitas pejalan kaki yang digunakan untuk penyeberangan pada ruas jalan yang ramai dan padat, menyeberang jalan tol, atau jalur kereta api, sehingga pejalan kaki terpisah secara fisik dan mengurangi kemungkinan terjadinya kecelakaan. Jembatan penyeberangan juga digunakan untuk menuju perhentian bus seperti busway Trans. Dikarenakan posisinya yang lebih tinggi dari tanah, untuk mempermudah akses kepada kaum disabilitas yang menggunakan kursi roda, maka disediakan ram (Fidel, 1997).

\section{Faktor-faktor yang Mempengaruhi Penggunaan Jembatan Penyeberangan}

Menurut O’Flaherty dalam Black (2001), faktor yang mempengaruhi penggunaan fasilitas penyeberangan tidak sebidang, diurutkan berdasarkan yang terpenting menurut pejalan kaki adalah :

1. Jarak (directness of route)

2. Kemudahan (ease of negotiation)

3. Estetik (interest of specific features)

4. Pertimbangan lingkungan (general enviromentl appeal)

5. Keselamatan(safety)

Menurut Hartarto dalam Jayadinata (1999), pejalan kaki enggan menggunakan jembatan karena malas, capai serta kondisi jembatan yang tidak menyenangkan seperti ketinggian jembatan, sempt dan terjal, kondisi kotor. Pejalan kaki lebih memilih mengambil resiko untuk menyebrang jalan karena merasa lebih praktis. Hal ini menyebabkan penyeberangan sebidang adalah median jalan yang digunakan sebagai penyeberangan.

Hal ini diperkuat dengan penjelasan dari Black (2001) dimana untuk meningkatkan penggunaan jembatan penyeberangan perlu di aplikasikan pagar pembatas di tepi jalan dan atau di tengah jalan sehingga jika memilih menggunakan penyeberangan sebidang harus menempuh rute yang lebih panjang atau malah sama sekali tidak mungkin dilakukan (Fidel, 1997).

\section{PENGUMPULAN DATA}

Dalam penelitian ini penentuan variabel untuk mengukur tingkat kepuasan pengguna jasa terhadap pelayanan sebagaimana disebutkan Kotler dalam Supranto, 1997 meliputi 7 dimensi kualitas pelayanan yaitu: keselamatan, keamanan, kemudahan, kelancaran, kenyamanan, keterpaduan system, dan daya tarik. Berikut merupakan variabel penelitian terkait aspek kualitas pelayanan JPO, yang disajikan dalam Tabel 1 dibawah ini. 
Tabel 1. Variabel Penelitian Kualitas Pelayanan JPO

\begin{tabular}{|c|c|c|}
\hline Aspek & Variabel & Sub Variabel \\
\hline \multirow{7}{*}{ Kualitas Pelayanan } & Kes elamatan (safety) & $\begin{array}{l}\text {-Lantai JPO tidak licin, lapuk, dan berlubang. } \\
\text {-Pagar pembatas yang rapat. }\end{array}$ \\
\hline & Keamanan (security) & $\begin{array}{l}\text {-Perlu ada penjaga JPO } \\
\text {-Penerangan JPO dimalam hari }\end{array}$ \\
\hline & $\begin{array}{l}\text { Kemudahan } \\
\text { (convenience) }\end{array}$ & -Warna JPO yang mencolok dan mudah dikenali \\
\hline & $\begin{array}{l}\text { Kelancaran } \\
\text { (continuity) }\end{array}$ & $\begin{array}{l}\text {-Tidak adanya PKL, pengemis/gelandangan di } \\
\text { sekitar JPO yang menghambat lajunya pengguna }\end{array}$ \\
\hline & Kenyamanan (comfort) & $\begin{array}{l}\text {-Pegangan tangan yang mampu dijangkau } \\
\text { pengguna dan tidak karatan. } \\
\text {-Dimensi anak tangga yang nyaman untuk dinaiki. } \\
\text {-Papan iklan yang tidak mengganggu pandangan } \\
\text { pengguna untuk melihat keadaan ke bawah. } \\
\text { •Pagar pembatas yang memakai ukuran tertentu dan } \\
\text { rapat. } \\
\text { •Bangunan JPO yang dapat mengurangi getaran } \\
\text { saat kendaraan melaju kencang } \\
\text { •Memungkinkan area yang luas untuk berjalan } \\
\text { •JPO terjaga kebersihannya } \\
\text { •Memungkinkan agar terhindar dari panas dan } \\
\text { hujan }\end{array}$ \\
\hline & $\begin{array}{l}\text { Keterpaduan system } \\
\text { (system coherence) }\end{array}$ & $\begin{array}{l}\text {-Lokasi JPO yang mudah dijangkau untuk menuju } \\
\text { halte angkutan umum, atau tempat-tempat umum. }\end{array}$ \\
\hline & $\begin{array}{l}\text { Daya Tarik } \\
\text { (attractiveness) }\end{array}$ & $\begin{array}{l}\text {-Desain JPO sudah atau sessuai keingian pejalan } \\
\text { kaki. }\end{array}$ \\
\hline
\end{tabular}

Analisis penting-kinerja (importance performance analysis) dapat digunakan untuk merangking berbagai elemen dari kumpulan jasa dan mengidentifikasi tindakan yang diperlukan. Martilla dan Jams dalam (Zeithaml dkk, 1996) menyarankan penggunaan metode Importance-Performance Analysis dalam mengukur tingkat kepuasan pelayanan jasa. Pada analisis Importance-Performance Analysis, dilakukan pemetaan menjadi 4 kuadran untuk seluruh variabel yang mempengaruhi kualitas pelayanan. Pembagian kuadran dalam Importance-Performance Analysis dapat dilihat sebagai berikut.

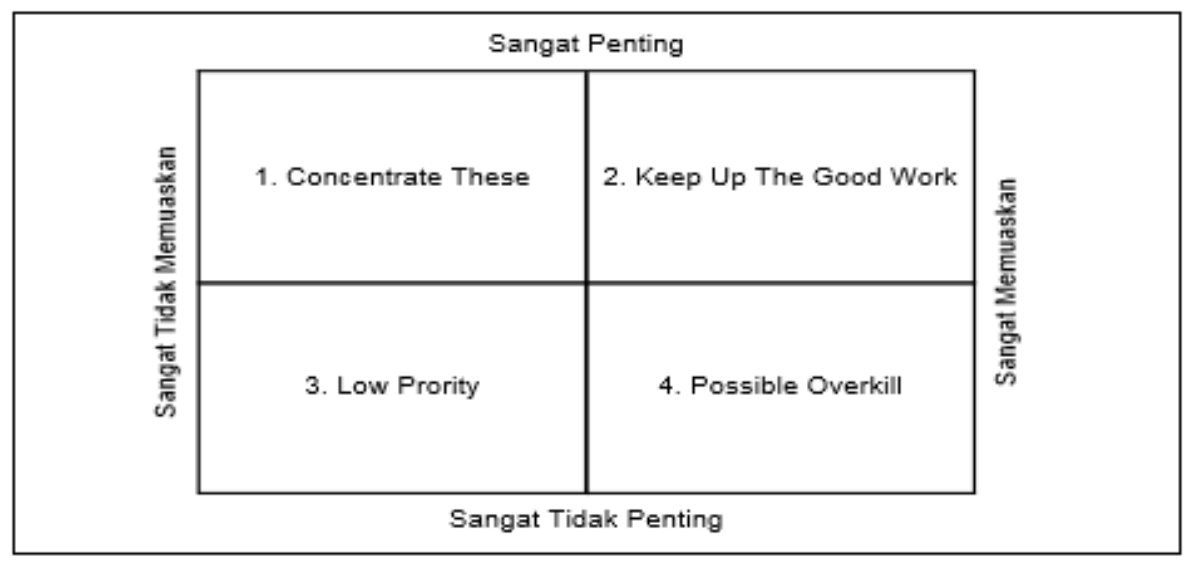

Gambar 1. Importance - Performance Analysis Matrix 


\section{PEMBAHASAN}

Penelitian ini dilakukan untuk mengkaji kepuasan pengguna terhadap fasilitas jembatan penyeberangan orang (JPO) dengan menggunakan variabel dan indikator kualitas pelayanan sebagai acuan. Untuk mendapatkan informasi mengenai hal tersebut maka penelitian ini dilakukan dengan menggunakan metode obsevasi, survey wawancara melalui instrument kuisioner dan metode dokumentasi untuk mengetahui kinerja dan kualitas pelayanan jembatan penyeberangan orang (JPO). Lokasi pengambilan data dilakukan pada 3 titik jembatan penyeberangan orang yang berbeda titik pertama adalah dikawasan depan SMAN 6 Surabaya, titik kedua berlokasi didepan Surabaya Plaza, titik ketiga berlokasi didepan UNAIR kampus. Data yang didapat kemudian diolah menggunakan analisis kuadran dan analisis deskriptif dengan memprosentase tiap-tiap variabel penelitian untuk dikaji.

Pengumpulan data dilakukan dengan menyebarkan kuesioner kepada 120 responden. Responden dalam penelitian ini adalah pengguna jembatan penyeberangan orang (JPO) Surabaya. Responden mengisi kuesioner yang berisi pertanyaan tentang penilaian fasilitas jembatan penyeberangan orang (JPO) di kota Surabaya. Selain itu dilakukan wawancara kepada responden untuk memperoleh informasi pendukung yang memperkuat analisis dan keakuratan data yang sudah didapatkan dari isian kuesioner.

\section{Profil Pengguna JPO}

Responden yang diamati dalam studi ini adalah pengguna JPO kota Surabaya yang berjumlah 120 responden. Jumlah responden tersebut diperoleh informasi karakteristik dari responden meliputi, pendidikan responden, pendapatan responden, pekerjaan responden, dan tujuan perjalanan responden.

\section{a. Karakteristik Responden Berdasarkan Pendidikan}

Berdasarkan data responden yang terkumpul 120 responden yang dijadikan sampel dalam penelitian ini diperoleh informasi mengenai karakteristik responden berdasarkan pendidikan dapat dilihat pada Gambar 2.

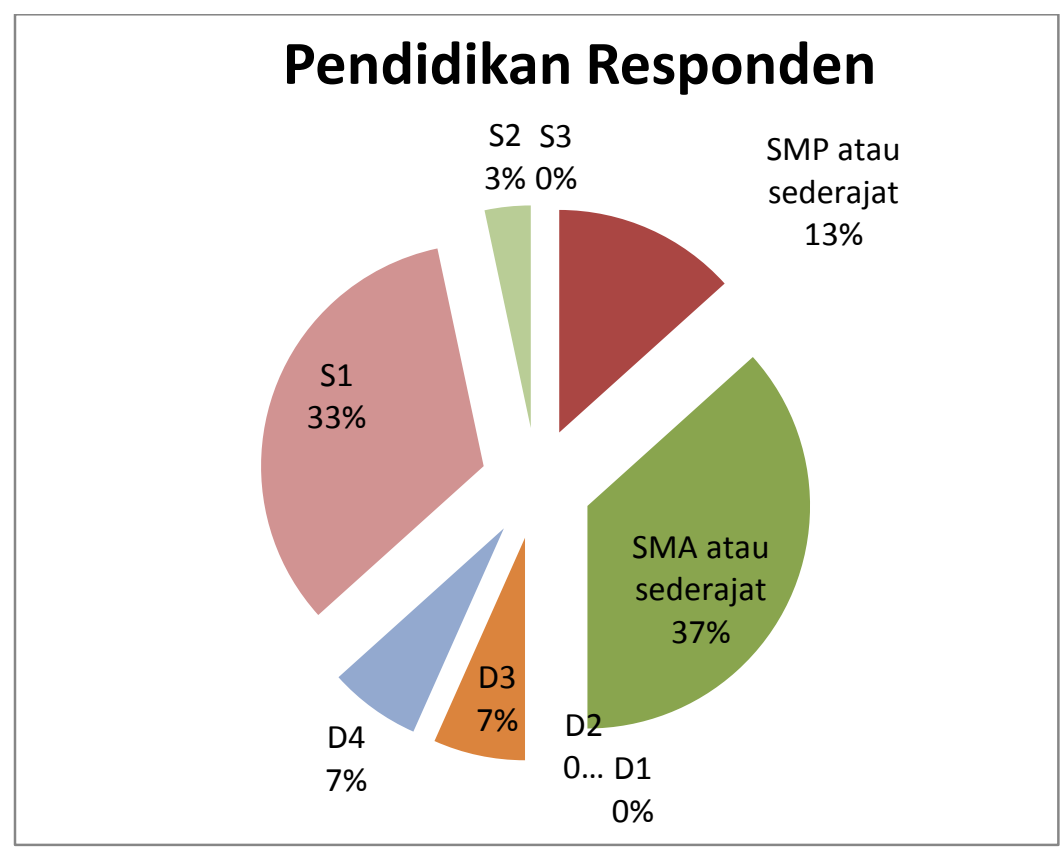

Gambar 2. Responden Berdasarkan Pendidikan 


\section{b. Karakteristik Responden Berdasarkan Pekerjaan}

Berdasarkan data responden yang terkumpul 120 responden yang dijadikan sampel dalam penelitian ini diperoleh informasi mengenai karakteristik responden berdasarkan pekerjaan dapat dilihat pada Gambar 3.

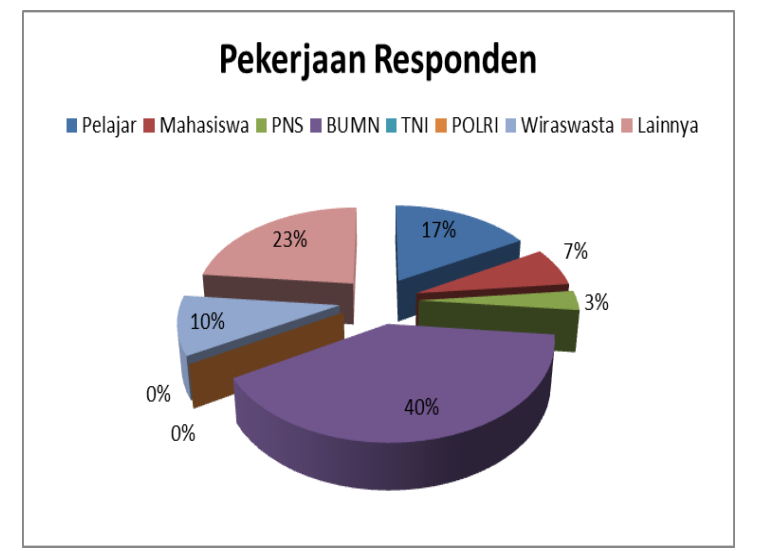

Gambar 3. Responden Berdasarkan Pekerjaan

\section{c. Karakteristik Responden Berdasarkan Penghasilan}

Berdasarkan data responden yang terkumpul 120 responden yang dijadikan sampel dalam penelitian ini diperoleh informasi mengenai karakteristik responden berdasarkan penghasilan dapat dilihat pada Gambar 4.

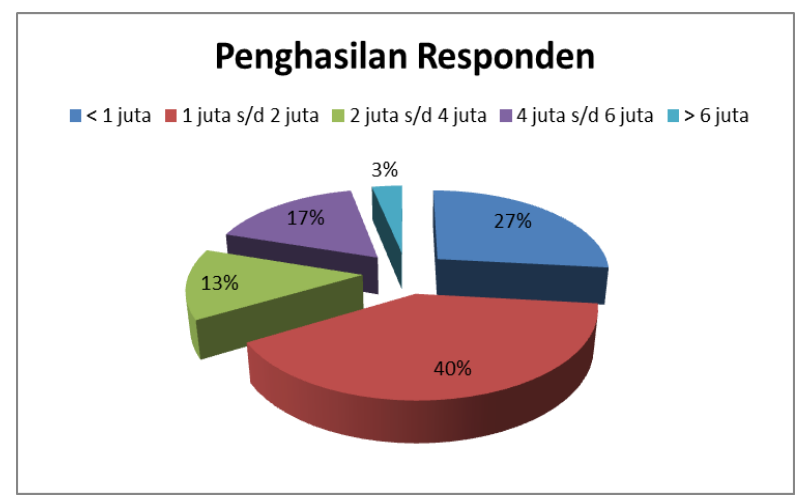

Gambar 4. Responden Berdasarkan Penghasilan

\section{d. Karakteristik Responden Berdasarkan Frekuensi Penggunaan fasilitas JPO}

Berdasarkan data responden yang terkumpul 120 responden yang dijadikan sampel dalam penelitian ini diperoleh informasi mengenai karakteristik frekuensi penggunaan fasilitas JPO dapat dilihat pada Gambar 5. 


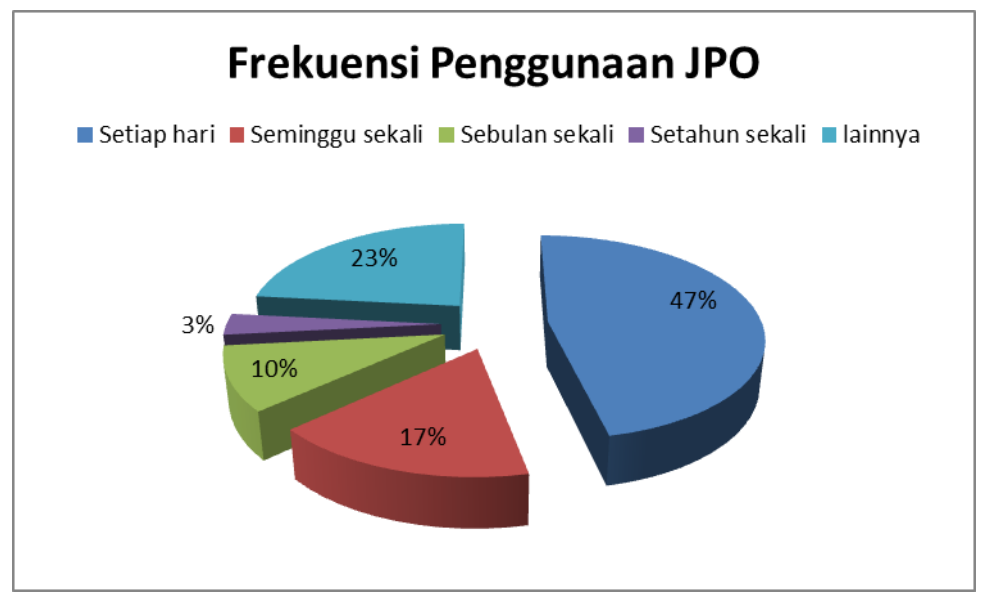

Gambar 5. Responden Berdasarkan Frekuensi Penggunaan Fasilitas JPO

\section{e. Karakteristik Responden Berdasarkan Kepentingan Perjalanan}

Berdasarkan data responden yang terkumpul 120 responden yang dijadikan sampel dalam penelitian ini diperoleh informasi mengenai karakteristik responden berdasarkan kepentingan perjalanan dapat dilihat pada Gambar 6.

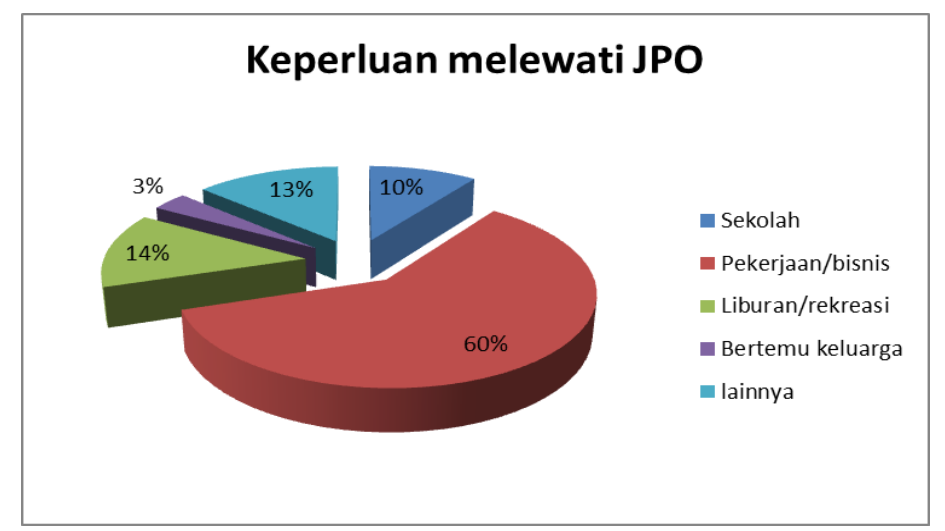

Gambar 6. Responden Berdasarkan Kepentingan Perjalanan

\section{Tingkat Kepuasan Fasilitas JPO Di Kota Surabaya Berdasarkan Penilaian Pengguna}

Analisis ini memetakan antara tingkat harapan konsumen dan tingkat kinerja. Garis vertikal mewakili penting atau tidaknya suatu dimensi kualitas pelayanan dimata konsumen dan garis horizontal menunjukkan tingkat kinerja dari setiap dimensi kualitas pelayanan. Semakin ke atas dinilai semakin penting, sedangkan semakin ke kanan dinilai semakin baik.

Lokasi penempatan JPO hendaknya diletakkan di titik-titik yang menjadi pusat dari kegiatan masyarakat. Berdasarkan survey lokasi eksisting diketaui bahwa lokasi penempatan JPO telah berada di titik-titik pusat kegiatan masyarakat. Adapun lokasi penempatan JPO yaitu titik pertama dikawasan depan SMAN 6 Surabaya, titik kedua berlokasi didepan Surabaya Plaza, titik ketiga berlokasi di Jalan Profesor Dr. Mustopo.

Berdasarkan data yang diperoleh dari hasil survey, diperoleh nilai rata-rata dari penilaian tingkat harapan dan tingkat kinerja menurut pengguna JPO. Adapun nilai rata-rata dari tiap-tiap dimensi kualitas pelayanan yang mempengaruhi tingkat kepuasan pengguna JPO dapat dilihat pada gambar diagram kartesius tingkat harapan dan tingkat kinerja tiap-tiap dimensi sebagai berikut: 


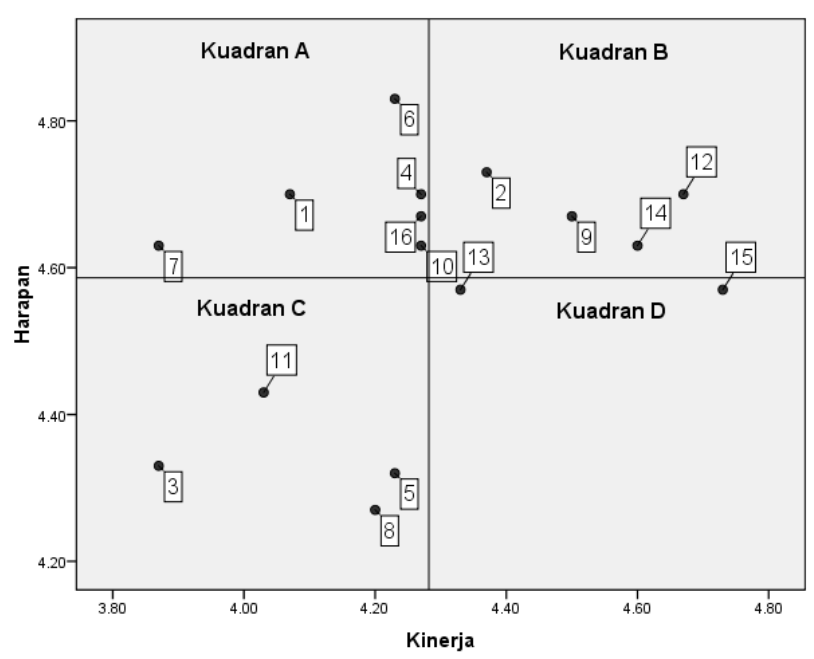

Gambar 7. Diagram Kartesius IPA Pengguna JPO pada titik 1 (SMAN 6 Surabaya)

Diagram Kartesius menunjukkan posisi dari setiap dimensi kualitas pelayanan berdasarkan tingkat kinerja dan tingkat harapan. Berdasarkan pada gambar 7 diketahui bahwa indikator yang berada pada kuadran A adalah atribut 1 (lantai JPO tidak licin, lapuk, dan tidak mudah berlubang), 4 (perlu adanya penjaga JPO), 6 (pegangan tangan yang mampu dijangkau pengguna dan tidak karatan), 7 (bentuk anak tangga yang nyaman untuk dinaiki), 10 (bangunan JPO yang dapat mengurangi getaran saat kendaraan melaju kencang), dan 16 (desain JPO sudah atau sesuai dengan keinginan pejalan kaki).

Atribut yang terletak pada kuadran A adalah atribut yang dianggap penting oleh pengguna, akan tetapi pelaksanaannya masih kurang baik maka perlu adanya perhatian khusus untuk meningkatkan kinerja, sehingga dapat meningkatkan kepuasan pengguna .

Pada titik 2 (Plaza Surabaya) diperoleh gambar diagram kartesius dari rata-rata penilaian tingkat harapan dan tingkat kinerja tiap-tiap dimensi sebagai berikut :

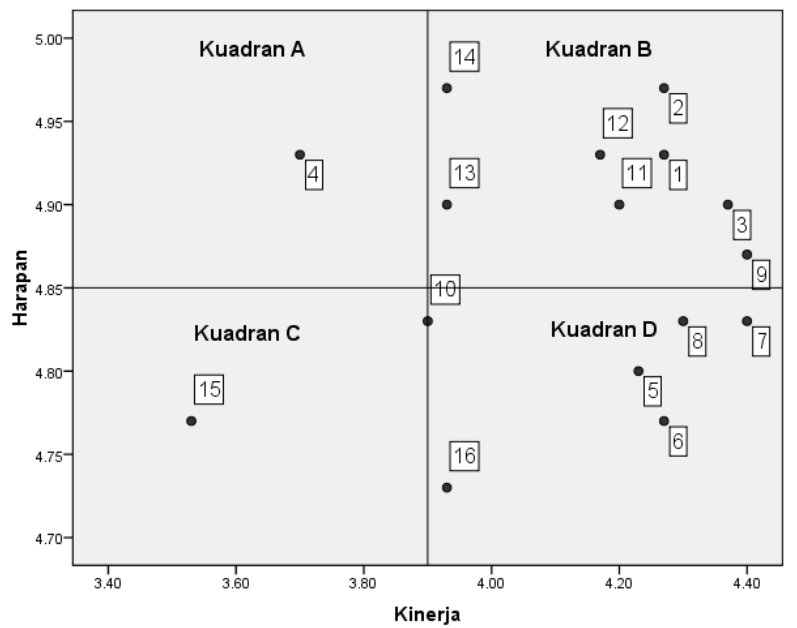

Gambar 8. Diagram Kartesius IPA Pengguna JPO pada titik 2 (Plaza Surabaya)

Berdasarkan gambar 8 diketahui bahwa yang berada di kuadran A, yaitu kuadran priorotas utama untuk dilakukan perbaikan yaitu atribut 4 (perlu adanya penjaga JPO). Sementara pada Titik 3 (Jalan Profesor Dr. Mustopo) diperoleh gambar diagram kartesius dari rata-rata penilaian tingkat harapan dan tingkat kinerja tiap-tiap dimensi sebagai berikut : 


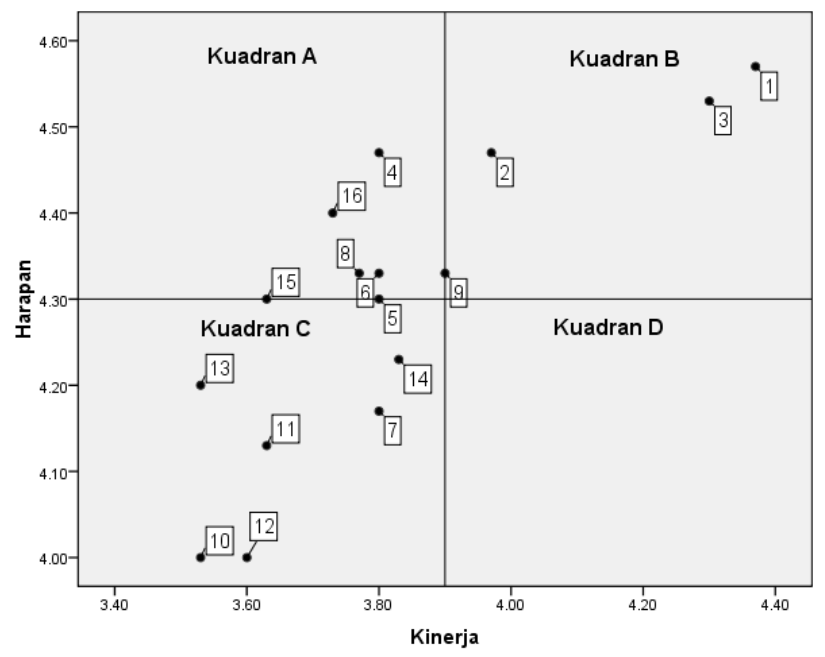

Gambar 9. Diagram Kartesius IPA Pengguna JPO pada titik 3 (Jl. Prof Dr. Mustopo)

Berdasarkan gambar 9 diketahui bahawa yang berada di kuadran A, yaitu kuadran priorotas utama untuk dilakukan perbaikan yaitu atribut 4 (perlu adanya penjaga JPO), atribut 5 (ruang bebas dari PKL, pengemis/ gelandangan disekitar JPO yang menghambat lajunya pengguna), atribut 6 (pegangan tangan yang mampu dijangkau pengguna dan tidak karatan), atribut 8 (papan iklan yang tidak mengganggu pandangan pengguna untuk melihat keadaan dibawah), atribut 9 (pagar pembatas yang memakai ukuran sudah sesuai dan rapat), dan atribut 15 (lokasi JPO mudah dijangkau untuk menuju halte angkutan umum, atau tempattempat umum).

\section{KESIMPULAN}

Pembahasan faktor-faktor yang mempengaruhi kepuasan pengguna jalur penyeberangan orang (JPO) pada kawasan pelayanan strategis skala regional di Kota Surabaya dapat disimpulkan beberapa hal, sebagai berikut :

- Pada JPO dititik 1 atribut yang terletak pada kuadran A adalah atribut 1 (lantai JPO tidak licin, lapuk, dan tidak mudah berlubang), 4 (perlu adanya penjaga JPO), 6 (pegangan tangan yang mampu dijangkau pengguna dan tidak karatan), 7 (bentuk anak tangga yang nyaman untuk dinaiki), 10 (bangunan JPO yang dapat mengurangi getaran saat kendaraan melaju kencang), dan 16 (desain JPO sudah atau sesuai dengan keinginan pejalan kaki).

- Pada JPO dititik 2 atribut yang terletak pada kuadran A, yaitu kuadran priorotas utama untuk dilakukan perbaikan yaitu atribut 4 (perlu adanya penjaga JPO).

- Pada JPO dititik 3 atribut yang terletak pada kuadran A yaitu, atribut 4 (perlu adanya penjaga JPO), atribut 5 (ruang bebas dari PKL, pengemis/ gelandangan disekitar JPO yang menghambat lajunya pengguna), atribut 6 (pegangan tangan yang mampu dijangkau pengguna dan tidak karatan), atribut 8 (papan iklan yang tidak mengganggu pandangan pengguna untuk melihat keadaan dibawah), atribut 9 (pagar pembatas yang memakai ukuran sudah sesuai dan rapat), dan atribut 15 (lokasi JPO mudah dijangkau untuk menuju halte angkutan umum, atau tempat-tempat umum). 


\section{DAFTAR PUSTAKA}

Anonymous. (2019). "Pedestrian Bridges Make Cities Less Walkable. Why Do Cities Keep Building Them?" Institute for Transportation \& Development Policy. https://www.itdp.org/2019/10/01/pedestrian-bridges-make-cities-less-walkable-why-docities-keep-building-them/. Diakses tanggal 10 Oktober 2019.

Black, J.A. (2001). Urban Transport Planning: Theory and Practice. Cromm Helm. London.

Coppola \& Y. Golombek. (2018). "Urban clear zones , street trees , and road safety". Research in Transportation Business \& Management, Volume 29, December 2018, Pages 136-143. Diambil dari DOI: https://doi.org/10.1016/j.rtbm.2018.09.003

Dong, X. Cao, X. Wu \& Y. Dong. (2019). "Examining pedestrian satisfaction in gated and open communities: An integration of gradient boosting decision trees and impactasymmetry analysis". Landscape and Urban Planning, Volume 185, May 2019, Pages 246-257. Diambil dari DOI: https://doi.org/10.1016/j.landurbplan.2019.02.012

Fidel, M. (1997). Sistem Transportasi Kota. Penerbit Tarsito. Bandung.

Giglio, J.M., Friar, J.H. \& Crittenden, W.F. (2018). "Integrating life-cycle asset management in the public sector". Business Horizons. Volume 61, Issue 4, July-August 2018, Pages 511-519. Diambil dari DOI: 10.1016/j.bushor.2018.03.005

Golias, G. Yannis, E. Papadimitriou, S. Lassarre, \& A. Banos. (2004). "Modelling Crossing Behavior And Accident Risk Crossing Behavior Model". Journal of Transportation Engineering, November 2007, 133(11):634-644. Diambil dari DOI: 10.1061/(ASCE)0733-947X(2007)133:11(634)

Iamtrakul \& J. Zhang. (2015). "Measuring Pedestrians' Satisfaction of Urban Environment Under Transit Oriented Development ( TOD ): A Case Study Of Bangkok". Lowland Technology International, December 2014. 16(2):125-134. Diambil dari DOI: 10.14247/lti.16.2_125

Jayadinata, J. T. (1999). Tata Guna Lahan Dalam Perncanaan Pedesaan Perkotaan dan Wilayah. Penerbit ITB. Bandung.

Kim, S. P. \& J. Seung. (2014). "Meso- or micro-scale ? Environmental factors influencing pedestrian satisfaction". Transportation Research Part D: Transport and Environment, Volume 30, July 2014, Pages 10-20. Diambil dari DOI: https://doi.org/10.1016/j.trd.2014.05.005

Lakhotia, S., Lassarre, K. R. R. \& G. Tiwari. (2019). "Pedestrian accessibility and safety around bus stops in Delhi," IATSS Research, Volume 44, Issue 1, April 2020, Pages 5566. Diakses dari DOI: https://doi.org/10.1016/j.iatssr.2019.07.001.

Mateo-Babiano, I. (2016). "Pedestrian's needs matters: Examining Manila's walking environment". Transport Policy. Volume 45, January 2016, Pages 107-115. Diambil dari DOI: https://doi.org/10.1016/j.tranpol.2015.09.008.

Mateo-Babiano, I., Tang, H., Conejos, S. \& Chan, E. H. W. (2016). “A63 Is an Active City a Healthier City for the Elderly? Examining Hong Kong's Active Transport Planning and SOT-14 Active Travel \& Health," J. Transp. Heal., Vol. 3, No. 2, pp. S42-S43.

Pešic, N. Milutinovic \& M. Maslac. (2016). "Pedestrian behaviours: Validation of the Serbian version of the pedestrian behaviour scale". Transportation Research Part F Traffic Psychology and Behaviour, June 2016, 41. Diambil dari DOI: 10.1016/j.trf.2016.02.004

Shah, R., McMann, O. \& Borthwick, F. (2017). Challenges and prospects of applying asset management principles to highway maintenance: A case study of the UK. Transportation Research Part A: Policy and Practice. Volume 97, March 2017, Pages 231-243. 
Soemitro, R.A.A. \& Suprayitno, H. (2018). "Pemikiran Awal tentang Konsep Dasar Manajemen Aset Fasilitas". Jurnal Manajemen Aset Infrastruktur \& Fasilitas, Vol. 2, Sup. 1. Juni 2018.

Tamin, O.Z. (2000). Perencanaan dan Pemodelan Transportasi. Edisi 2. Penerbit ITB. Bandung.

Warpani, S. (1990). Merencanakan Sistem Perangkutan. Penerbit Institut Teknologi Bandung. Bandung.

Yannis, J. Golias \& E. Papadimitriou. (2007). Modeling Crossing Behavior and Accident Risk of Pedestrians. Journal of Transportation Engineering, 133(11):634-644. Diambil dari DOI: 10.1061/(ASCE)0733-947X(2007)133:11(634).

Zeithaml, Valarie A., Leonard L. Berry and A. (1996). Parasuraman The Behavioral Consequences of Service Quality. Journal of Marketing, Vol. 60: 31-46, No. 2. April 1996. Diambil dari DOI: https://doi.org/10.2307/1251929. 
(e)ISSN 2615-1847 (p)ISSN 2615-1839

Jurnal Manajemen Aset Infrastruktur \& Fasilitas - Vol.5, No.1, Januari 2021 